\title{
Sonnet to the Brain
}

Jimmy Li

Neurology ${ }^{\circledR}$ 2021;96:491. doi:10.1212/WNL.0000000000011379
Correspondence

Jimmy Li

jimmy.li@umontreal.ca

When lightning flies across a starlit sky,

I often meditate thine artful form

And see that very lightning ramify

Like lustrous roots-an oaken thunderstorm.

O Brain! Thy royal throne a humble stem

Through which commands in seamless fashion flow.

Thine arborescent lambency a gem;

An ancient arbor vitae's afterglow.

Afloat inside a palace built with bone,

Thou mustn't claim thy keep cannot be harmed!

For every monarch, favored or unknown,

A host of fiendish foes stay ably armed.

Such grievous ailments splinter through thy prime;

Our quest for thee shall soothe thine aches with time. 


\title{
Neurology
}

\author{
Sonnet to the Brain \\ Jimmy Li \\ Neurology 2021;96;491 Published Online before print December 22, 2020 \\ DOI 10.1212/WNL.0000000000011379
}

This information is current as of December 22, 2020

$\begin{array}{ll}\begin{array}{l}\text { Updated Information \& } \\ \text { Services }\end{array} & \begin{array}{l}\text { including high resolution figures, can be found at: } \\ \text { http://n.neurology.org/content/96/10/491.full }\end{array} \\ \text { Subspecialty Collections } & \begin{array}{l}\text { This article, along with others on similar topics, appears in the } \\ \text { following collection(s): } \\ \text { History of Neurology } \\ \text { http://n.neurology.org/cgi/collection/history_of_neurology }\end{array} \\ \text { Permissions \& Licensing } & \begin{array}{l}\text { Information about reproducing this article in parts (figures,tables) or in } \\ \text { its entirety can be found online at: } \\ \text { http://www.neurology.org/about/about_the_journal\#permissions }\end{array} \\ \text { Reprints } & \begin{array}{l}\text { Information about ordering reprints can be found online: } \\ \text { http://n.neurology.org/subscribers/advertise }\end{array}\end{array}$

Updated Information \&

Subspecialty Collections

http://n.neurology.org/subscribers/advertise

Neurology ${ }^{\circledR}$ is the official journal of the American Academy of Neurology. Published continuously since 1951, it is now a weekly with 48 issues per year. Copyright (C 2020 American Academy of Neurology. All rights reserved. Print ISSN: 0028-3878. Online ISSN: 1526-632X.

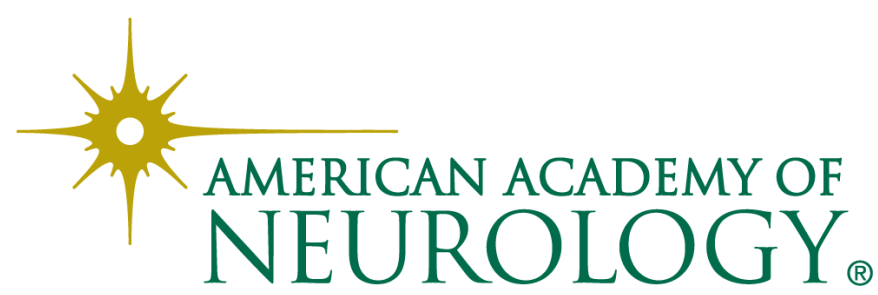

